University for Business and Technology in Kosovo

UBT Knowledge Center

UBT International Conference

2014 UBT International Conference

Nov 7th, 3:00 PM - 3:15 PM

\title{
Citizenship and ethnic relations in Kosovo
}

Bekim Baliqi

University for Business and Technology, baliqi@ubt-uni.net

Follow this and additional works at: https://knowledgecenter.ubt-uni.net/conference

Part of the Communication Commons, and the Political Science Commons

\section{Recommended Citation}

Baliqi, Bekim, "Citizenship and ethnic relations in Kosovo" (2014). UBT International Conference. 29.

https://knowledgecenter.ubt-uni.net/conference/2014/all-events/29

This Event is brought to you for free and open access by the Publication and Journals at UBT Knowledge Center. It has been accepted for inclusion in UBT International Conference by an authorized administrator of UBT Knowledge Center. For more information, please contact knowledge.center@ubt-uni.net. 


\title{
Citizenship and ethnic relations in Kosovo
}

\author{
Bekim Baliqi \\ Media \& Communication \\ UBT, Kosovo \\ bekim.baliqi@ubt-uni.net
}

\begin{abstract}
The article explores the issue of multi-ethnic society, by looking at the state iconography, the citizenship issue as well as ethnic relations based on Kosovo as a case study. The theoretical framework is based on the power-sharing model known as consociationalism democracy. Research methods applied here are based mainly in discourse analysis and in content analysis of relevant documents, literature and other sources. The inter-ethnic relations between Serbs and Albanians will be traced historically from the period after the Second World War, following with the dissolution of Yugoslavia and Milosevic's regime, continuing with the post-conflict period in Kosovo through to the declaration of Kosovo's Independence. Then different levels and diverse aspects of the relationship will be explored.

The issues of citizenship will be discussed as relevant research topics. The next part of research addresses state symbols and their impact on ethnic relations and integrations efforts. Finally, the conclusions will be presented and summarized, including a brief discussion of questions of multi-ethnic society and civic identity in Kosovo.
\end{abstract}

Keywords:Citizenship,multi-ethnicity,consociationalism, identity,Kosovo.

\section{Introduction}

The collapse of communist regimes in Eastern and Southeastern Europe was followed by the revival of nationalist activities and a recurrence of ethnic animosities. While ethnic affiliation provides a basis for political solidarity, it can also underpin resentment and conflict among ethnic groups. This kind of ethnic hatred and consequently violent conflicts were manifested in several former republics of Yugoslavia, and in particular in Kosovo. Peace building, ethnic reconciliation and democratization of these postconflict states, depend very much on rebuilding trust between former conflicting parties but also from identity building and national unity.

The process of political and social integration and of the peaceful coexistence is a difficult and highly fragile process which is often characterized by tensions and challenges stemming from interactions of demos and ethnos, politics and justice, society and economy, culture and the past. Illustrations of these difficulties could be useful for countries-entities of the former Yugoslavia, such as Bosnia and Herzegovina, Macedonia and Kosovo, where ethnic relations still play a critical role in the political life of these societies and states. Based on the case study of Kosovo, I am trying to illustrate the complexity of the politics of identity and how this correlated with ethnic relations. This is done by posing the question 'whether power-sharing arrangements are able to invent or 'construct' identity that goes beyond ethnic belongings'.

Multi-ethnic states face immense difficulties and challenges to build sustainable peace and to establish a democratic society and institutions. Deeply divided societies, with a high level of ethnic polarization among communities, are widely regarded to be more exposed to violent conflicts or more specifically to conflicts of ethnic nature. Therefore, the crucial challenge for peace building and polity settlement in Kosovo was: how to solve conflict in this divided society and how to arrange institutions that manage ethnic relations between former conflicting groups? One of the most prominent models of solutions is that of consociational democracy, which includes institutional, constitutional, electoral and power sharing arrangements. It was first identified by ArendLijphart in his seminal work "Democracy in Plural Societies: A comparative exploration." 
Kosovo's state-building, created as a result of an internationally negotiated plan, through Comprehensive Proposal for Kosovo Status Settlement also known as Ahtisaari's Plan, entails these 'power-sharing' arrangements, hence could serve as appropriate example of consociational model. The central questions which are raised here are: how citizenship isrelated to ethnic relations and vice versa, and can consociationalism democracy influence this processes?

\section{Theoretical framework}

Multi-ethnic states face immense difficulties and challenges to build sustainable peace and to establish a democratic society and institutions. Deeply divided societies, with a high level of ethnic polarization among communities, are widely regarded to be more exposed to violent conflicts or more specifically to conflicts of ethnic nature. According to Tajfel and Turner, identity, be it national or ethnic, is a function of one's group membership. This identity is made ever more salient by focusing on the positive characteristics of that group, which supposedly are not possessed by members of other groups. In this context, when ethnicity is constitutional part of the identity and when that identity is threatened in some way, then ethnocentrism is a result. ${ }^{161}$ That consequently led to conflicting identities, whereby justification of one side identity was in complete rejection of the identity of the other side, as was the case in the conflict in Kosovo.

The issue of how political settlements are to be adopted in divided and/or post-conflict societies have received growing attention not only in the academic world, but also in decision-making circles of international community. Therefore, the crucial challenge for peace building and polity settlement in Kosovo was: how to solve conflict in this divided society and how to arrange institutions that manage ethnic relations between former conflicting groups? One of the most prominent models of solutions is that of consociational democracy, which includes institutional, constitutional, electoral and power sharing arrangements. It was first identified by Arend Lijphart in his seminal work "Democracy in Plural Societies: A comparative exploration." 162 Although the focus in this book was mainly in mitigating tensions in democratic societies, analysis seems to be useful also for states in transitions especially in the post-conflict societies. It could include various arrangements, including models of grand coalition governments in which all ethnic groups are represented, segmental autonomy (as in case of Kosovo through decentralization of local government according to the so called Ahtisaari Plan), election proportionality and minority veto. ${ }^{163}$ It may involve following types of practices: territorial autonomy and federal or confederal arrangements, communal federations in ethnic basis, proportional representation in administration, proportional electoral system and consensus decision rules, legal framework and guarantee of minority rights etc. ${ }^{164}$ Consociationalism is an approach to democratic development in divided societies, emphasizing elite cooperation and institutional engineering by the creation of stable multi-ethnic coalition government.

Kosovo's state-building, created as a result of an internationally negotiated plan, through Comprehensive Proposal for Kosovo Status Settlement also known as Ahtisaari's Plan, entails these 'power-sharing' arrangements, hence could serve as appropriate example of consociational model. ${ }^{165}$ In terms of electoral arrangements, as consociationalism suggests, Kosovo applies the proportional electoral system that enable ethnic groups to be represented in the parliament in proportion to their numbers and non-majority groups have additional guaranteed and over-proportional number of twenty seats in the Kosovo's parliament. Introduction of the electoral proportional system, with additional

${ }^{161}$ Tajfel, H, / Turner, J. C., "The social identity theory of intergroup behaviour'. In S.Worschel\&W.Austin (Eds.), Psychology of intergroup relations. Chicago: Nelson Hall 1986.

162Arend Lijphart, Democracy in Plural Societies: A Comparative Exploration, New Haven: Yale University Press, 1977.

163Ibid.

${ }^{164}$ Timothy D. Sisk, Power Sharing and International Mediation in Ethnic Conflicts, Washington, D.C.: US Institute of Peace, 1996 pg.47-67.

${ }^{165}$ Comprehensive proposal forKosovo Status Settlement, United Nations S/2007/169/Add.1 
protection of communities through reserved seats as well as imposing minority participation in executive institutions are some of the main consociational mechanisms in the process of state building in Kosovo. Constitutional design is also in spirit of consociational democracy, whereby the Republic of Kosovo is defined as multi-ethnic state and provides specific right for non-majority communities. The questions that need to be considered in this respect are: does consociatonal democracy offer equal representation and rights for all, and thus contribute to the creation of a shared civic identity, or in does it contribute to the further and greater ethnic division? Some scholars raise similar concerns, stating that the power-sharing arrangements can impose habits of ethnic competition and distrust into newly emerging institutions that can hardly or cannot at all manage conflict. ${ }^{166}$

Although the idea of consociational democracy is to encourage inter-group or inter-ethnic trust through a culture of co-operation which begins with political elites and continues to all communities' members, it tells very little about the identity issue. Among factors which improve chances of successful implementation of consociational democracy, according to Lijphart, is also the external threat. Lijphart argues that a threat to the state from an external power serves to unite the disputing factions, giving them common cause against a mutual enemy and helping to forge a common identity. ${ }^{167}$ As a matter of fact, in the case of Kosovo, external threat (mainly coming from Serbia that strongly opposes Kosovo's statehood) plays a counter-effect in building a common supra-ethnic identity. Moreover, potential threat from another country (in this case from Serbia) only increases ethnic division and political mobilization along ethno-national lines. In this regard, consocionalism democracy through above mentioned mechanism seems to support promotion of multi-ethnic identity implicitly through institutional and political cooperation between ethnic groups. But it does not tell clearly what kind of identity politics should be implemented and how ethnic relations can develop beyond these power-sharing settlements. It is also unclear whether power-sharing strengthens or weakens loyalties and commitment to the state and political unity?

Therefore, to explore identity issue and ethnic relations, the article will examine official state symbols such as for example state flag, anthem, seal, discourses about them and the citizenship issue through a more semiotic and interpretative approach.

There is a lack of surveys conducted in Kosovo that would provide empirical evidence about how or to what extent ethnic relations have influenced development of citizenship and shared civic identity formation. But most likely improvement of these relations will have an impact on state legitimacy and will affect political unity. Apart from that, manifestation of a common civic identity through state iconography, ceremonies and sports or cultural events is increasingly taking place. Although ethnonational flags (Albanian or Serbian) are still present in most cultural or traditional events or in election campaigns.

\section{State Symbols}

Symbols are means of identification; moreover they are a constitutive element of identification. The states and nations are represented through their own and distinctive symbols; this make them more apparent and can increase commitment of the citizens to their state. As prominent Nationalism scholar Montserrat Guibernau explains: „Symbols not only stand for or represent something else, they also allow those who employ them to supply part of their meaning, they do not impose upon people "the constraints of uniform meaning'." 168 Thus, the symbolic components have a functional task; they link and unite members of a community separating them from the others defined by other symbols. In other words, symbols represent and manifest the identity of a particular community. Especially in postconflict and divided societies, symbols are closely linked to national myths and narratives and serve as an integral part of daily political discourse.

\footnotetext{
${ }^{166}$ Chandra Lekha Sriram, Peace as Governance-Power-Sharing, Armed Groups and Contemporary Peace Negotiations,Basingstoke Palgrave 2008, pg.vi.

${ }^{167}$ Lijphart p. 160

168Montserrat Guibernau, Nationalism. The Nation-State and Nationalism in the Twenty-first Century. Cambridge, Polity 1996,pg. 81.
} 
In order to reconcile ethnic groups and create preconditions for a democratic and multi-ethnic society, international community (UNMIK, OSCE and KFOR) initially used own symbols in public institutions and gradually proclaimed 'neutral' to any ethnic symbols. The Kosovo Police Service (KPS) was the first institution that introduced a symbol (the geographical projection of Kosovo), as a supra-ethnic icon which could be acceptable for all ethnic communities. Later on also the Kosovo Protection Corps (KPC) and many other institutions and authorities used that symbol as its own representation emblem. The United Nations Mission in Kosovo (UNMIK) established an approved coat of arms for the Provisional Institutions of Self Government in July 2003, in accordance with its administrative direction. ${ }^{169}$

Similar to the controversies about the national histories and identity issue, also the debate about state symbols such as the flag, coat of arms and anthem were and still are politically very sensitive themes. The fear of "replacements" of existing ethno-national symbols is perceived by both ethnic communities as a national betrayal. ${ }^{170}$ But attempts and initiatives to establish own state symbols were not really absent: thus the Kosovo Albanian leader and first Kosovo's president, Ibrahim Rugova, introduced in October 2000, a "state" flag and anthem of Kosovo. The flag was blue, inscribed with a red disc with a golden ring. Inside the red disc is the Albanian eagle. The eagle is holding a ribbon with the legend "Dardania" inscribed. Dardania is the name of an ancient Illyrian tribe and region in the area as it is Kosovo nowadays. Also the song "Kur karakushtrimin'Kosove" composed by Rauf Dhomi was presented as the official anthem of the Republic of Kosovo. However, these symbols were not accepted by all political forces and did not gain much popularity of the broad mass. But it is still used as an unofficial presidential standard and often by the Democratic League of Kosovo (LDK), the political party founded by Rugova.

In June 2007, the Assembly of Kosovo decided to announce an international competition for the design of state symbols including flag, anthem and coat of arms, which attracted almost one thousand entries. The preconditions were, as foreseen by Ahtisaari plan that these symbols could not be the same or similar to national symbols of other states, which mean that the Albanian and Serbian two-headed eagle and the use of the color combinations red-black or blue-white-red are not allowed. The Ahtisaari's Plan for Kosovo provides following proposal: „Kosovo shall have its own, distinct, national symbols, including a flag, seal and anthem, reflecting its multi-ethnic character. "'171

The flag of Kosovo was adopted by the Assembly immediately following the declaration of independence of the Republic of Kosovo on 17. February 2008. It has a blue background, charged with a map projection of Kosovo and six stars in an arc above. The stars are officially meant to symbolize Kosovo's six major ethnic groups. ${ }^{172}$ The flag symbolize also a multi-ethnic character of the state, as defined by the constitution. ${ }^{173}$ Also the coat of arms was adopted by the parliament on the same day and is identical with content of the flag, with the difference that it is placed on a rounded triangular shield and has a golden rim. National anthem of the Republic Kosovo titled "Europe" was adopted by Assembly of Kosovo in 11 June 2008. The anthem has no lyrics and contains no references to any specific ethnic group with the intention to avoid possible misinterpretations and refusal.

Similar to the debate about the state flag, discussions in the public opinion about the anthem were controversial, because it was perceived as imposed from foreigners and opposed the "national values" and as such was an attempt to replace the "real" ethno-national anthem (of Albanians).This is due to the fact that Kosovar Albanians as majority population consider that these symbols do not reflect their political will and cultural legacy, whereas other communities and mostly Kosovo Serb minority perceive this as a threat of domination or assimilation. Because of their strong political connotation over a long period, national symbols of ethnic communities will continue to play a significant role. Better acceptance and sentimental ties with the state symbols can develop together with the growing state legitimacy and in the longer term.

${ }^{169}$ UNMIK Administrative Direction No.2003/15, see:

http://www.unmikonline.org/regulations/admdirect/2003/ade2003_15.pdf

${ }^{170}$ For more onthis debate see; Bekim Baliqi, Zur Frage der nationalen Identität am

Beispiel des Kosovos, Dipl. Arbeit , Universitat Wien 2005 pg.110-124.

171 The Comprehensive Proposal for Kosovo Status Settlement, Article 1.7

${ }^{172}$ See. Gezim Aliu: "Flamuri i ri. Tri Interpretime", 20. February. 2008 in:

http: / / www.telegrafi.com/?id=268a $=247$ (accesson 21.05.2014)

${ }^{173}$ Constitution of the Republic of Kosovo, Chap. I, Art. 6 
On the day of declaration of independence, a monument in yellow color making the word in English language 'Newborn' with its metaphorical meaning was inaugurated in downtown Pristina. In the process of normalization of ethnic relations and socio-political integration towards shared civic identity, supra-ethnic symbols are important yet insufficient steps. As a matter of fact, narrative and educational aspects on and about identities are critical in this process. Thus ethnic relations in Kosovo are characterized by opposing and antagonistic view of symbols and identities. In this context, moving from the ethnicity as a rigid and basic determinant of the belongings to the more open and multilayer civic identity is not only a constitutive element in the state building but also in the peace building and democratization process.

\section{Citizenship and multi-ethnicity}

Because of the unresolved status, also the citizenship issue in Kosovo was for a long period uncertain. During the UNMIK administration citizens of Kosovo were defined only as residents not as citizens of Kosovo. Immediately after the declaration of independence of Kosovo, the Assembly adopted the Law on Citizenship, which allows dual citizenship and does not involve any ethnic preconditions. Indeed, the law is ethnically neutral, addressing only the issue of citizenship (shtetësia, državljanstvo) but not nationality in the legislation. It is in the spirit of Ahtisaari's Plan for an inclusive society and reflects attempts of international community to build a democratic and multiethnic state. However, its controversy is that it gives more space and rights to communities, that are based merely and exclusively on ethnic affiliation and not on citizenship. Hence, this legislation does not use the term Kosovars in any of its provisions. The first Chapter (Basic Provisions) of the Constitution of the Republic of Kosovo states the following: "The Republic of Kosovo is a multi-ethnic society consisting of Albanian and other Communities, governed democratically with full respect for the rule of law through its legislative, executive and judicial institutions." 174

The concept of citizenship implies a commitment to a sovereign state; this contains and establishes rights, duties, status and loyalty for all its citizens regardless of their ethnic origin. But the identity politics in Kosovo in its confusion of the "ethnicity" concept, does not promote citizenship as loyalty and responsibility to a state. The civic and multi-ethnic concept should be encouraged building on cultural, political and ethnic diversity, for the citizens of Kosovo to define themselves, instead by their ethnic affiliation. Thus citizenship also raises the question of the socio-political integration and identity politics. The process of formation of a Kosovar identity through citizenship, similar to all post-conflict societies, encounters significant difficulties in consolidating its statehood and constituting the initial body of its citizens. However, it is the political "we-feeling" among Kosovo citizens that is progressively increasing - with the partial exception of the Kosovo Serbs in the North of the country. In this sense, Simonsen earlier recognized that:

"Nation building in Kosovo that encompasses not only the Albanians (inclusive nation building) may seem far-fetched since majority and minority members barely come close enough to talk anymore. However, it is useful to see nation building as a wider span of processes than what normally occurs. In such a perspective a sense of community among citizens may be virtually absent, but there may nevertheless be structures and policies at play facilitating its development". ${ }^{175}$

With regard to the citizenship that is regulated constitutionally, citizens of Kosovo have a legal status and may travel, identify and represent their state abroad but it is not sufficient to build a strong tie between citizens and the state. Bearing in mind de facto statelessness during the period of 'parallel system' in the 1990s and de jure statelessness during the UNMIK administration until 2008, citizenship regime in the newly independent state provides an opportunity to develop a common political body and state unity. However, it still remains open if citizenship as a formal membership in a state is sufficient to forge and consolidate a Kosovar identity.

${ }^{174}$ Constitution of the Republic of Kosovo, Chap. I, Art. 3.

175Simonsen, pg.291 


\section{Conclusion}

Dealing with the past is often politically misused by both ethnic communities beginning from school and street names to the public and academic discourses. The trauma of war, past events and the selfperception as victims, play a crucial role in the definition of ethnic relations and consequently in peace building process.

Only after the end of armed conflict and setting of UN administration, the efforts for peace negotiations toward conflict resolution and ethnic reconciliation could really take place. Since the dissolution of Yugoslavia, series of international negotiations have attempted to resolve the question of Kosovo status and to improve or normalize ethnic relations. As Marc Weller precisely puts in: "The international administration of the crisis, from the virtual abolition of Kosovo's autonomy by Slobodan Milosevic in 1988 to the territory's declaration of independence in 2008, drew on virtually the entire arsenal of international conflict management tools, from negotiation to good offices, conference diplomacy, mediation and even coercive diplomacy - including the threat, and eventual use, of force." 176

Normalization of ethnic relations and eventually reconciliation requires the development of the society, economic prosperity and mutual trust between ethnic groups. Therefore, reconciliation goes beyond conflict resolution and addresses the social and emotional barriers to improve ethnic relations. In this context, peace negotiations influence ethnic relations and consequently identity formation process. But it is early to predict how and to what extent the negotiations will impact the citizenship in Kosovo. Although, constitution and institutional arrangements define Kosovo as a state of its citizens, the sentimental loyalty and self-identification of communities are primarily on the basis of ethnic affiliation. This research paper and the study carried out found that despite the wide implementation of 'powersharing' arrangements in accordance with the model of consociational democracy, shared civic identity have not been constituted. Consociationalism may contribute more or less to alleviating ethnic divisions through institutional engineering and political arrangements but not necessarily overcome contested identities or support consolidation of citizen identity. This due to tense ethnic relations, lack of state legitimacy, ethno-political elites, economic conditions and other factors that have important role in the formation of identity. The acceptance of state iconography as part of cultural and emotional aspect is growing gradually although national-ethnic ones are still widely used. Another aspect examined here, was the political and legal aspect around the citizenship issue that makes the basis for loyalty beyond ethnicity, but in the case of Kosovo it is still not a sufficient tool for identity building. Last but not least important in this study were the negotiations between Prishtina and Belgrade that could lead to improvement of ethnic relations and consequently to state loyalty as a precondition for the identity formation. But the main obstacles remains, Belgrade's paternalistic attitude toward Kosovo Serbs and their refusal of Kosovo statehood. Some of the main findings are that there is lack of political will of existing political elites to improve ethnic relations therefore citizenship have not contributed to develop citizenry that goes beyond ethno-national sentiments.

\section{Reference}

1. Aliu, Gezim: "Flamuriiri. Tri Interpretime", 20 February 2008.

2. Clark,Howard: Civil Resistance in Kosovo. London, Pluto Press, 2000.

3. Comprehensive proposal for Kosovo Status Settlement, United Nations.

4. Constitution of the Republic of Kosovo.

5. Goodwin, Morag: From Province to Protectorate to State? Speculation on the Impact of Kosovo's Genesis upon the Doctrines of International Law, in: German Law Journal, Special Issue - What Future for Kosovo? Vol.8 No.1, 2007.

6. Guibernau, Montserrat: Nationalism. the Nation-State and Nationalism in the Twenty-first Century. Cambridge, Polity 1996.

7. International Crisis Group: Kosovo's Ethnic Dilemma. The Need for a Civic Contract. Balkans ReportNo. 143, 28 May 2003.

176Marc Weller, 'Kosovo's final status', in: Internationa lAffairs, 84 (6) 2008, pg. 1239. 
8. Jenkins, B./Sofos, S. A. (Ed.) Nation \& Identity in Contemporary Europe. London, Routledge, 1996.

9. Lijphart, Arend, Democracy in Plural Societies: A Comparative Exploration, New Haven: Yale University Press, 1977.

10. Malcolm, Noel: Kosovo. A short History: New York, New York University Press, 1998.

11. Matveeva,A./Paes, W.-Ch.: The Kosovo Serbs: An ethnic minority between collaboration and defiance, BIIC, Bonn, June 2003.

12. Schmidt, Thomas (Ed.): Krieg im Kosovo. Hamburg, Rowohlt, 1999.

13. Simonsen,Sven Gunnar: Nation building as Peace building: Racing to Define the Kosovar, in: International Peacekeeping, Nr.2 Vol.11 2004.

14. Sisk, Timothy D.:Power Sharing and International Mediation in Ethnic Conflicts, Washington, D.C.: US Institute of Peace, 1996.

15. Sriram, Chandra Lekha: Peace as Governance- Power-Sharing, Armed Groups and Contemporary Peace Negotiations, Basingstoke Palgrave 2008.

16. The Comprehensive Proposal for Kosovo Status Settlement.

17. UNDP: Pubic Pulse Report VI, Pristina, August 2013.

18. UNMIK Administrative Direction No.2003/15.

19. Weller, Marc: Kosovo's final status. International Affairs, 84 (6) 2008.

20. Weller, Marc: The Vienna negotiations on the final status for Kosovo, in; International Affairs 84: 4, 2008.

21. Worschel, S./Austin, W. (Eds.), Psychology of intergroup relations. Chicago: Nelson Hall 1986. 